\title{
Synthesis, Characterization, and Antimicrobial Activity Studies of Ni(II) Complex with Pyridine as a Ligand
}

\author{
Faridul Islam, ${ }^{1}$ Md. Amran Hossain, ${ }^{2}$ Nur Mostaq Shah, ${ }^{3}$ Hridika Talukder Barua, ${ }^{4}$ \\ Md. Alamgir Kabir, ${ }^{5}$ Mohammad Jamshed Khan, ${ }^{2}$ and Romel Mullick ${ }^{6}$ \\ ${ }^{1}$ Bangladesh Council of Scientific and Industrial Research Laboratories Chittagong, Chittagong 4220, Bangladesh \\ ${ }^{2}$ Department of Chemistry, Chittagong College, Chittagong, Bangladesh \\ ${ }^{3}$ Department of Chemistry, Chittagong University, Chittagong 4341, Bangladesh \\ ${ }^{4}$ Department of Microbiology, Chittagong University, Chittagong 4341, Bangladesh \\ ${ }^{5}$ Department of Chemistry, Government H. S. S. College, Magura, Bangladesh \\ ${ }^{6}$ Directorate General of Drug Administration, Dhaka, Bangladesh
}

Correspondence should be addressed to Faridul Islam; faridacct@yahoo.com

Received 4 January 2015; Accepted 20 February 2015

Academic Editor: Jae Ryang Hahn

Copyright (C) 2015 Faridul Islam et al. This is an open access article distributed under the Creative Commons Attribution License, which permits unrestricted use, distribution, and reproduction in any medium, provided the original work is properly cited.

We represent a metal complex which has been synthesized by the simple reaction with $\mathrm{Ni}$ (II) chloride and pyridine (as a lignd) affording a complex having the molecular formula $\left[\mathrm{Ni}\left(\mathrm{C}_{5} \mathrm{H}_{5} \mathrm{~N}\right)_{2} \mathrm{Cl}_{2}\right]$, characterized on the basis of elemental analyses, electronic, infrared, ${ }^{1} \mathrm{H}$ NMR, ${ }^{13} \mathrm{C}$ NMR spectra, magnetic susceptibility, and also aid of molar conductivity measurement. Conductivity measurement reveals nonelectrolytic nature of the complex. IR and ${ }^{13} \mathrm{C}$ NMR spectra reveal the presence of $c i s$ - and trans-structure. On the basis of above analyses the square planar cis- and trans-structures are proposed for the prepared complex.

\section{Introduction}

Coordination complexes have persist an important and popular area of research due to their simple synthesis, adaptability, and different range of applications. From the existing literature, it seems that transition metal complexes played a vital role in the development of coordination chemistry $[1,2]$. It also plays an important role in biological process as exemplified in many instances in which enzymes are known to be activated by metal ions [3]. These complexes have been occupied in the strongest and transport of active substances through membrane [4]. Many metal complexes are resulting application in the microelectronic industry, chemical vapour deposition of metals, and drugs [5]. Coordination compounds display diverse characteristic properties which depend on the metal ion to which they are bound. On the basis of nature of the metal as well as the type of ligand, these metal complexes have wide applications in different fields of human curiosity $[6,7]$.
Pyridine is a heterocyclic organic compound with the chemical formula $\mathrm{C}_{5} \mathrm{H}_{5} \mathrm{~N}$ and is structurally related to benzene, with one $\mathrm{CH}$ group replaced by a nitrogen atom [8]. It is also a six-membered cyclic aromatic molecule with $\sigma$ and $\pi$ binding capabilities through its nitrogen electron lone pair and $\pi$ system, respectively, which has inspired considerable interests in its bonding with metals over the last decade. A number of experimental and theoretical investigations have established that most metal-pyridine complexes are $\sigma$ complexes [9-12]. It has importance in industrial organic chemistry, both as a fundamental building block and as a solvent and reagent in organic synthesis [13]. Pyridine derivatives also play significant role in many biological systems as the component of several vitamins, nucleic acids, enzymes, and proteins [14]. Pyridine derivatives have occupied a unique position in the field of medicinal chemistry. Some of them constitute an important class of antitumor compounds [15]. 2-Amino-3-cyanopyridines have been identified to possess antibacterial, [16] antimicrobial, 
TABLE 1: Analytical and physical data for the complex.

\begin{tabular}{|c|c|c|c|c|c|c|c|c|c|}
\hline \multirow{2}{*}{ Complex } & \multirow{2}{*}{ Color } & \multirow{2}{*}{ M. P. $\left({ }^{\circ} \mathrm{C}\right)$} & \multirow[b]{2}{*}{$\mathrm{C}$} & \multicolumn{4}{|c|}{ Calculated data \% (found) } & \multirow{2}{*}{$\begin{array}{l}\Lambda M \\
\mathrm{Ohm}^{-1} \mathrm{~cm}^{2} \mathrm{~mol}^{-1}\end{array}$} & \multirow{2}{*}{$\begin{array}{l}\mu_{\mathrm{eff}} \\
\text { B. M. }\end{array}$} \\
\hline & & & & $\mathrm{H}$ & $\mathrm{N}$ & $\mathrm{Cl}$ & $\mathrm{Ni}$ & & \\
\hline $\begin{array}{l}\left.\mathrm{Ni}\left(\mathrm{C}_{5} \mathrm{H}_{5} \mathrm{~N}\right)_{2} \mathrm{Cl}_{2}\right] \\
\text { Cis- }\left[\mathrm{Ni}\left(\mathrm{C}_{5} \mathrm{H}_{5} \mathrm{~N}\right)_{2} \mathrm{Cl}_{2}\right] \\
\text { Trans- }\left[\mathrm{Ni}\left(\mathrm{C}_{5} \mathrm{H}_{5} \mathrm{~N}\right)_{2} \mathrm{Cl}_{2}\right]\end{array}$ & $\begin{array}{c}\text { Yellow } \\
\text { Reddish yellow } \\
\text { Deep yellow }\end{array}$ & $\begin{array}{l}319 \\
360\end{array}$ & $\begin{array}{l}41.21 \\
(40.98)\end{array}$ & $\begin{array}{l}3.46 \\
(3.41)\end{array}$ & $\begin{array}{l}9.62 \\
(9.57)\end{array}$ & $\begin{array}{l}25.56 \\
(25.16)\end{array}$ & $\begin{array}{l}20.15 \\
(19.95)\end{array}$ & $\begin{array}{l}0.00\left(\text { in } \mathrm{CHCl}_{3}\right) \\
315\left(\text { in } \mathrm{H}_{2} \mathrm{O}\right)\end{array}$ & 0.00 \\
\hline
\end{tabular}

[17, 18] antifungal, [19] cardiotonic, [20] analgesic [21], antiinflammatory [22], and antilung cancer [23] activities.

Nickel is an important transition metal normally stable in aqueous solution in the +2 oxidation state [24]. It is important in biological system, which is a key factor affecting the production of secondary plant metabolites, thus influencing plant resistance to disease [25]. It interacts with iron found in the hemoglobin and helps in oxygen transport, stimulates the metabolism, and is regarded as a key metal in several plants and animal enzyme systems [26]. Nickel is involved in the transmission of genetic code (DNA, RNA) and it is also present in certain enzyme systems that metabolize sugars [27]. This metal is more attracted by the researchers in recent years, Many nickel complexes have been reported with their importance [28-31]. Nickel sulfate hexahydrate is used in nickel electroplating, Nickelocene is used as a catalyst and complexing agent, and nickel titanate is used as a pigment [32].

As a part of continuing interest in this area of research, we have investigated coordination behavior of square planar $\mathrm{Ni}$ (II) complex of pyridine. The complex has been characterized by spectral technique and thin-layer chromatography method. The new nickel(II) complex has also been screened for antibacterial and antifungal activities against various pathogenic bacteria and fungi.

\section{Experiment}

2.1. Materials and Methods. All the chemicals used were of analytical reagent grade. These were obtained from M/S E. Merck and used without further purification. The analysis of $\mathrm{C}, \mathrm{H}$, and $\mathrm{N}$ was performed on a vario MICRO Vi. $6.1 \mathrm{GmbH}$, Japan CHNS analyzer. Molar conductance of the complex was measured in water and chloroform at room temperature using a HANNA instrument with HI $8820 \mathrm{~N}$ conductivity cell. Magnetic susceptibility of the complex was performed on a Sherwood Scientific magnetic susceptibility balance. IR spectra were recorded as $\mathrm{KBr}$ disc in the range of $400-$ $4000 \mathrm{~cm}^{-1}$ on a Perkin-Elmer 883 and Shimadzu infrared spectrophotometer. Electronic spectra were run between 250 and $500 \mathrm{~nm}$ on a Shimadzu UV-visible spectrophotometer (model UV-1800) using $1 \mathrm{~cm}$ cell. ${ }^{1} \mathrm{H}-\mathrm{NMR}$ and ${ }^{13} \mathrm{C}-\mathrm{NMR}$ spectra were recorded on a Bruker $400 \mathrm{MHz}$ instrument using TMS as an internal reference. The NMR spectrum of the complexes under study was recorded from the Department of Chemistry and Biotechnology, Osaka University, Tottori, Japan. Melting points were measured with an electrothermal melting point apparatus. The Ni content of the prepared complex was done by complexometric titration method [33]. The purity of the complex was checked by TLC using silica gel $\mathrm{G}$ plates.

2.2. Synthesis of $\left[\mathrm{Ni}\left(\mathrm{C}_{5} \mathrm{H}_{5} \mathrm{~N}\right)_{2} \mathrm{Cl}_{2}\right]$ Complex. $23.77 \mathrm{~g}(0.1$ moles) $\mathrm{NiCl}_{2}$ was dissolved in $100 \mathrm{~mL}$ distilled ethanol with continuous stirring. The solution was greenish-blue in color and in this solution $8.05 \mathrm{~mL}$ ( 0.1 moles) pyridine was added dropwise with continuous stirring. The color of the mixture became deep blue instantly. The reaction mixture was stirred on a magnetic stirrer for further 2-3 hours. Then the mixture refluxed for about 10 hours in a water bath. The reaction mixture was then allowed to stand 30 hours. During this period a light yellow coloured precipitation started to form. To ensure the complete formation of the metal complex it was preserved for another 24 hours. Then the light yellow coloured nickelpyridine complex was separated by vacuum filtration. After separation the complex was washed by redistilled ethanol until the colourless filtrate is coming out. After washing, the complex was dried in a vacuum desiccator over silica gel.

\section{Result and Discussion}

The complex obtained is yellow colored microcrystalline powder and air stable, but soluble in water and chloroform. The results of elemental analysis $(\mathrm{C}, \mathrm{H}, \mathrm{N}, \mathrm{Ni}$, and $\mathrm{Cl}$ ) along with molecular formulae and melting points of the complex are presented in Table 1.

3.1. Infrared Spectral Data. The infrared spectrum of $\left[\mathrm{Ni}\left(\mathrm{C}_{5} \mathrm{H}_{5} \mathrm{~N}\right)_{2} \mathrm{Cl}_{2}\right.$ ] complex is shown in Figures 1 and 2 and the absorption bands are listed with the relative intensities along with tentative assignments of the various bands in Table 2. In the spectrum of the complex, absorption bands at $3020-3080 \mathrm{~cm}^{-1}$ and $1145-1220 \mathrm{~cm}^{-1}$ are due to the stretching vibration of $\mathrm{C}-\mathrm{H}$ and $\mathrm{C}-\mathrm{C}$, respectively. According to $\mathrm{Ni}-\mathrm{N}$ bonding [34], IR spectrum is found with $530-600 \mathrm{~cm}^{-1}$ In our prepared complex a nice IR band is found at $542 \mathrm{~cm}^{-1}$, $549.71 \mathrm{~cm}^{-1}$, and $557.43 \mathrm{~cm}^{-1}$ which are due to the stretching vibration of $\mathrm{Ni}-\mathrm{N}$ bond, which indicates that the formation of nickel-pyridine complex is a mixture and confirms it by TLC and separated into cis- and trans-product. The strong absorption bands at $1400-1500 \mathrm{~cm}^{-1}$ and medium intensity absorption peaks at $1550-1598 \mathrm{~cm}^{-1}$ are due to the stretching vibration of $\mathrm{C}=\mathrm{C}$ bond and $\mathrm{C}-\mathrm{N}$ bond $[34,35]$, respectively. The strong intensity absorption peaks at $1600-1650 \mathrm{~cm}^{-1}$ are due to the stretching vibration of $\mathrm{C}=\mathrm{N}$. We have found that 
TABLE 2: Infrared and electronic spectral data for the complex.

\begin{tabular}{|c|c|c|c|c|c|c|c|c|}
\hline \multirow{2}{*}{ Complex } & \multicolumn{7}{|c|}{ Infrared spectral data $\left(\mathrm{cm}^{-1}\right)$} & \multirow{2}{*}{$\begin{array}{l}\text { Electronic spectral bands } \\
(\mathrm{nm})\end{array}$} \\
\hline & $v_{\mathrm{C}-\mathrm{H}}$ & $v_{\mathrm{C}-\mathrm{C}}$ & $v_{\mathrm{C}=\mathrm{C}}$ & $v_{\mathrm{C}-\mathrm{N}}$ & $v_{\mathrm{C}=\mathrm{N}}$ & $\nu_{\mathrm{Ni}-\mathrm{N}}$ & $\nu_{\mathrm{Ni}-\mathrm{Cl}}$ & \\
\hline$\left[\mathrm{Ni}\left(\mathrm{C}_{5} \mathrm{H}_{5} \mathrm{~N}\right)_{2} \mathrm{Cl}_{2}\right]$ & $\begin{array}{l}3028.24 \\
3070.68\end{array}$ & 1155.36 & $\begin{array}{l}1448.54 \\
1489.05\end{array}$ & 1573.91 & 1606.70 & $\begin{array}{c}542.00, \\
549.71 \\
557.43\end{array}$ & $\begin{array}{l}688.59 \\
700.16\end{array}$ & $395,400,300$ \\
\hline Cis- $\left[\mathrm{Ni}\left(\mathrm{C}_{5} \mathrm{H}_{5} \mathrm{~N}\right)_{2} \mathrm{Cl}_{2}\right]$ & - & 1149.57 & 1485.19 & 1598.99 & 1600.92 & 511.14 & $\begin{array}{l}692.44 \\
694.37\end{array}$ & - \\
\hline
\end{tabular}

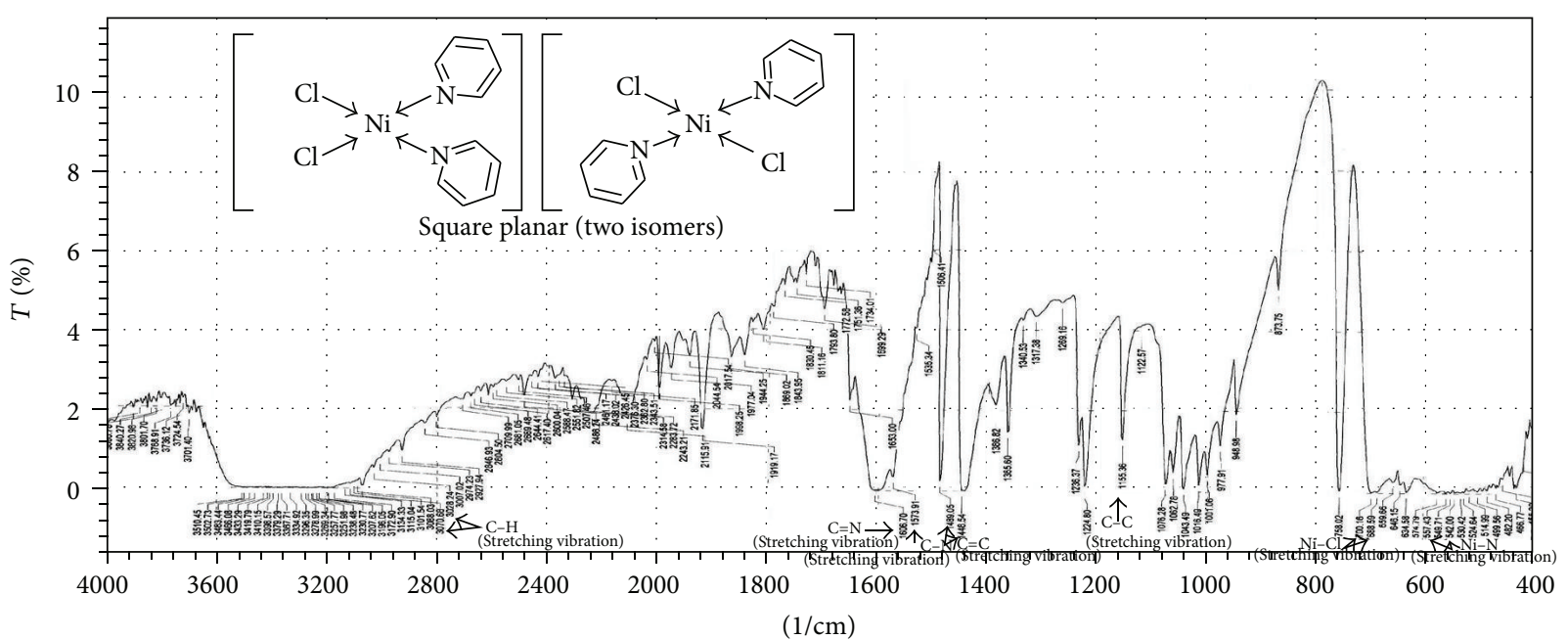

FIGURE 1: Infrared spectrum of $\left[\mathrm{Ni}\left(\mathrm{C}_{5} \mathrm{H}_{5} \mathrm{~N}\right)_{2} \mathrm{Cl}_{2}\right]$.

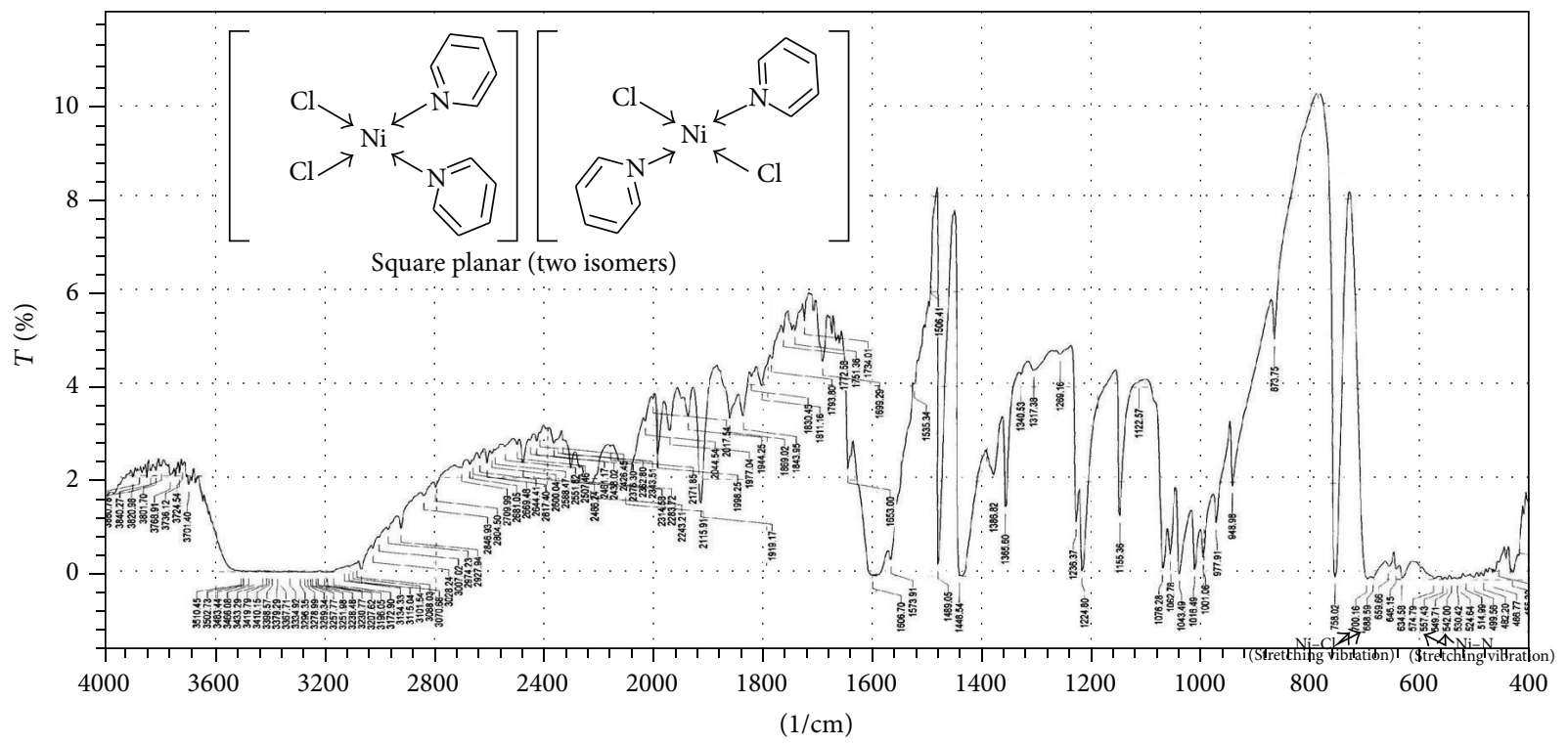

FIGURE 2: Infrared spectrum of $\left[\mathrm{Ni}\left(\mathrm{C}_{5} \mathrm{H}_{5} \mathrm{~N}\right)_{2} \mathrm{Cl}_{2}\right]$.

the strong intensity absorption peaks at $680-700 \mathrm{~cm}^{-1}$ are due to the stretching vibration of $\mathrm{Ni}-\mathrm{Cl}$ bond. According to $[36,37] \mathrm{Ni}-\mathrm{N}$ bonding, strong IR spectrum is found at $511.14 \mathrm{~cm}^{-1}$ and $588.29 \mathrm{~cm}^{-1}$ which indicates the formation of cis- and trans-configuration shown in Figures 3 and 4 due to the stretching vibration of Ni-N bond. From IR spectrum position the cis- and trans-configuration of square planar $\left[\mathrm{Ni}\left(\mathrm{C}_{5} \mathrm{H}_{5} \mathrm{~N}\right)_{2} \mathrm{Cl}_{2}\right]$ complex are confirmed.

3.2. Electronic and NMR Studies. The electronic spectrum of the complex displays Table 2 absorption band at $300 \mathrm{~nm}$ 


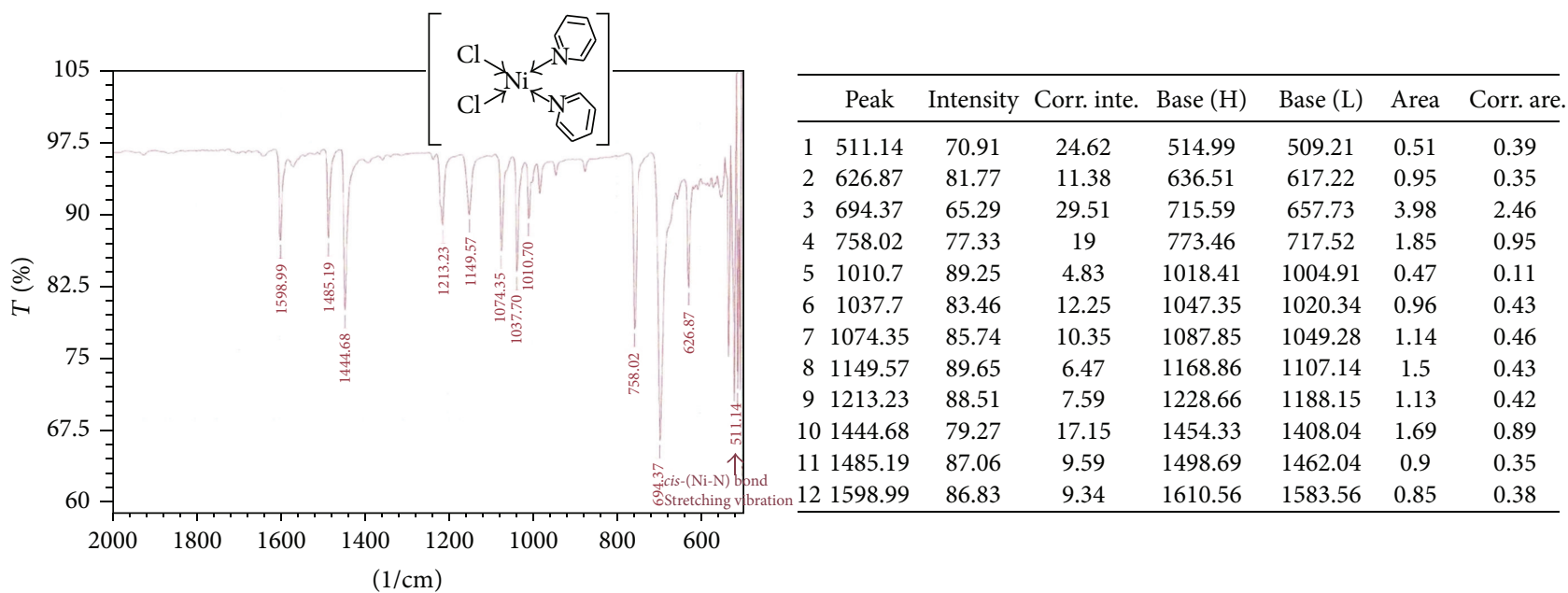

FIGURE 3: Infrared spectrum of $c i s-\left[\mathrm{Ni}\left(\mathrm{C}_{5} \mathrm{H}_{5} \mathrm{~N}\right)_{2} \mathrm{Cl}_{2}\right]$.

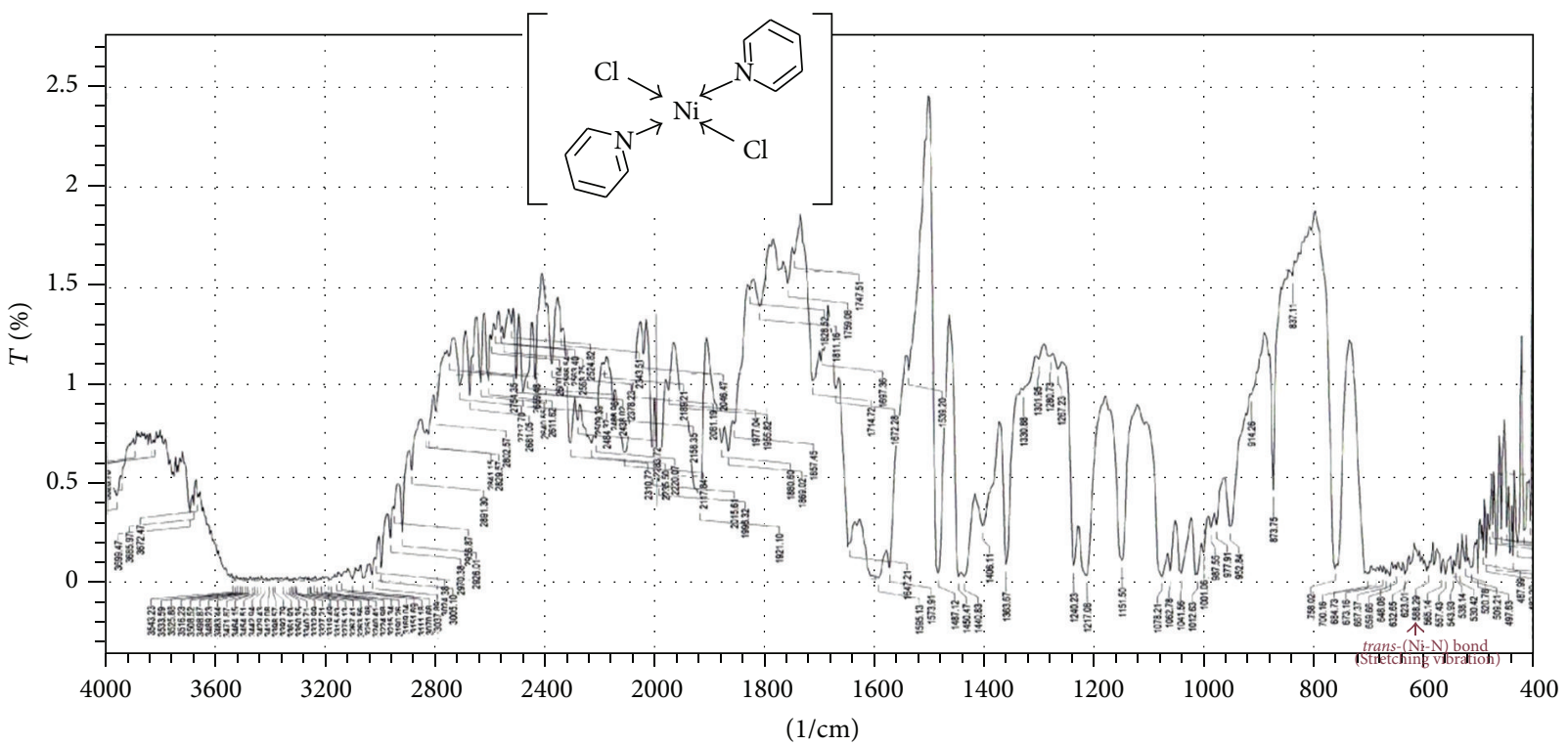

Figure 4: Infrared spectrum of trans- $\left[\mathrm{Ni}\left(\mathrm{C}_{5} \mathrm{H}_{5} \mathrm{~N}\right)_{2} \mathrm{Cl}_{2}\right.$.

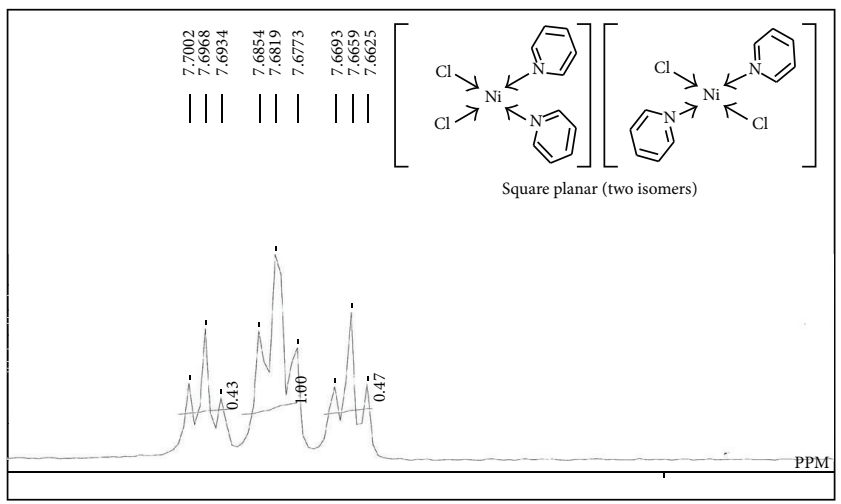

Figure 5: ${ }^{1} \mathrm{H}-\mathrm{NMR}$ spectral data for the complex $\left[\mathrm{Ni}\left(\mathrm{C}_{5} \mathrm{H}_{5} \mathrm{~N}\right)_{2} \mathrm{Cl}_{2}\right]$. 


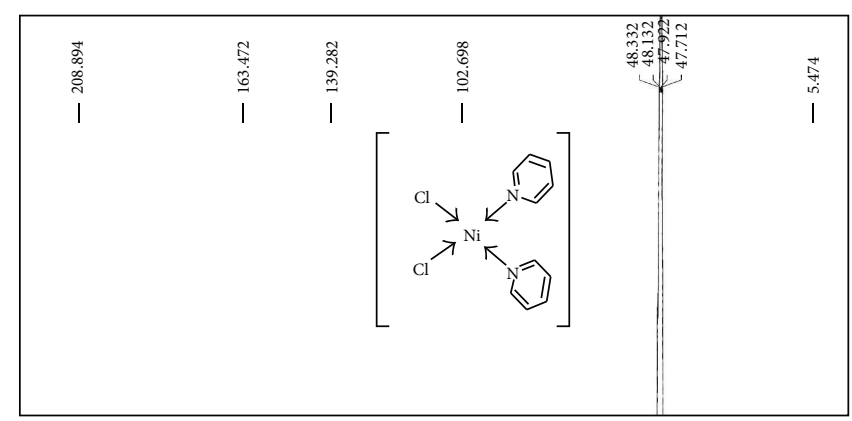

Figure 6: ${ }^{13} \mathrm{C}$-NMR spectrum of $c i s-\left[\mathrm{Ni}\left(\mathrm{C}_{5} \mathrm{H}_{5} \mathrm{~N}\right)_{2} \mathrm{Cl}_{2}\right]$.

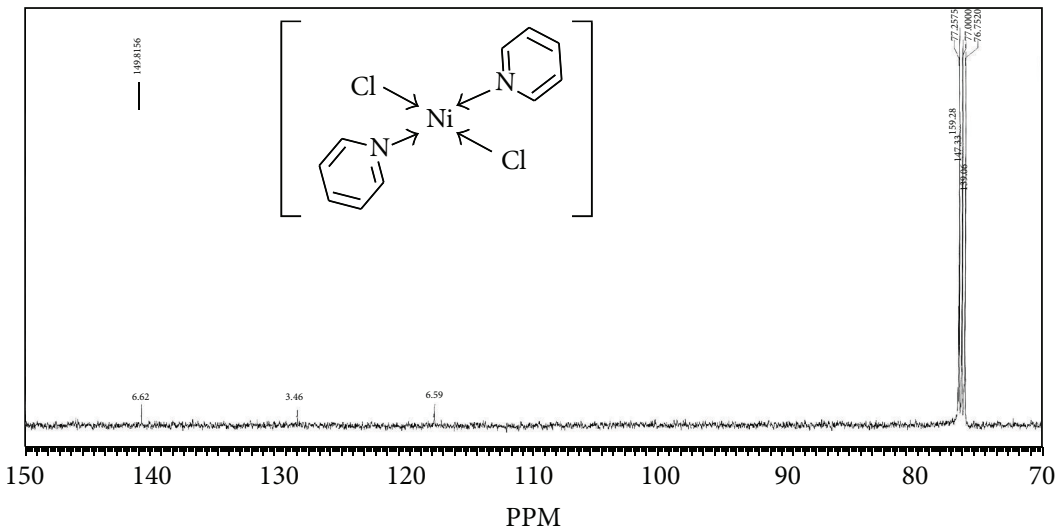

Figure 7: ${ }^{13} \mathrm{C}-\mathrm{NMR}$ spectrum of trans- $\left[\mathrm{Ni}\left(\mathrm{C}_{5} \mathrm{H}_{5} \mathrm{~N}\right)_{2} \mathrm{Cl}\right]$.

in the ultraviolet region which indicates that nickel-ligand charge transfer transition and absorption bands at 390$405 \mathrm{~nm}$ in water show the square planar geometry.

The ${ }^{1} \mathrm{H}-\mathrm{NMR}$ spectrum of $\mathrm{Ni}(\mathrm{II})$ complex shows in Figure 5 three triplet signals at 7.6625-7.6693 ppm being for the proton of $\mathrm{C}_{3}$ carbon. The second 7.6773-7.6854 ppm and third 7.6934-7.7002 ppm show for the protons of $\mathrm{C}_{2}, \mathrm{C}_{4}$ and $\mathrm{C}_{1}, \mathrm{C}_{5}$ carbons which are pairwise equivalent. But ${ }^{13} \mathrm{C}-\mathrm{NMR}$ spectra give a separate resonance for each stereochemically distinct carbon atom. The ${ }^{13} \mathrm{C}$-NMR spectra give additional evidences on the assignment of structures on the basis of ${ }^{1} \mathrm{H}$ NMR spectrum analysis.

The spectrum in Figure 6 exhibits four peaks at $102.698 \mathrm{ppm}, 139.282 \mathrm{ppm}, 163.472 \mathrm{ppm}$, and $208.894 \mathrm{ppm}$ which correspond to four nonequivalent carbon atoms. Among the four peaks, the second one at $139.282 \mathrm{ppm}$ is for the $\mathrm{C}_{2}$ and $\mathrm{C}_{4}$ carbon being pairwise equivalent. The first peak shows that the $\mathrm{C}_{3}$ carbon atom is comparatively more shielded, but the last two indicate that $\mathrm{C}_{1}$ and $\mathrm{C}_{5}$ carbons are highly deshielded compared to those of other ring carbons. According to the spectral position, the cis-conformation is fixed. Figure 7 shows three signals; $124 \mathrm{ppm}$ indicates that the $\mathrm{C}_{3}$ atom is comparatively more shielded than other ring carbons. The second (136 ppm) and third (150 ppm) signal exhibit the $\mathrm{C}_{2}, \mathrm{C}_{4}$ carbons and $\mathrm{C}_{1}, \mathrm{C}_{5}$ carbons, respectively, which are pairwise equivalent. However the last peak also indicates that $\mathrm{C}_{1}$ and $\mathrm{C}_{5}$ carbons are highly deshielded compared to those of other ring carbons. According to all NMR spectral positions the cis- and trans-conformation are confirmed.

3.3. Magnetic and Conductance Studies. The molar conductivity value of $0.00 \mathrm{ohm}^{-1} \mathrm{~cm}^{2}$ mole $\mathrm{e}^{-1}$ (Table 1) in chloroform strongly supports the nonelectrolytic nature of the complex; that is, all the anions are in the coordination sphere as expected for four coordinated square planar $\mathrm{Ni}$ (II) complexes. On the other hand, the molar conductivity value of 315 $\mathrm{ohm}^{-1} \mathrm{~cm}^{2}$ mole $\mathrm{e}^{-1}$ of the yellow coloured aqueous solution of this complex corresponding to $1: 2$ electrolytes provides evidence that di-aqua complex is formed by the complete replacement of $\mathrm{Cl}^{-}$ion by $\mathrm{H}_{2} \mathrm{O}$ molecules in aqueous solution. The magnetic moment value of the complex is 0.00 B.M. which corresponds to no unpair electron as expected for square planar nickel (II) complex.

3.4. Antimicrobial Studies. Transition metal coordination complexes play vital role in biological study; some of these have now been widely studied for their antimicrobial and anticancer properties [38] and extensive investigations in the field of metal complexes have been reported $[39,40]$. A novel $\mathrm{Ni}$ (II) complex has also been studied with its antimicrobial activities [41]. In the continuation of this discovery present studies synthesized a new $\mathrm{Ni}$ (II) pyridine complex and 


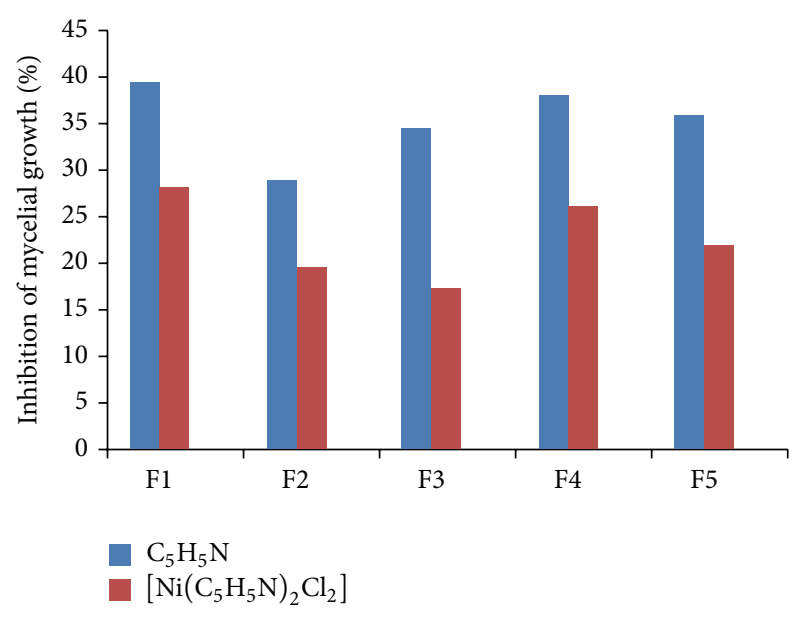

FIgURE 8: Inhibition of fungi mycelial growth by the tested ligand and complex.

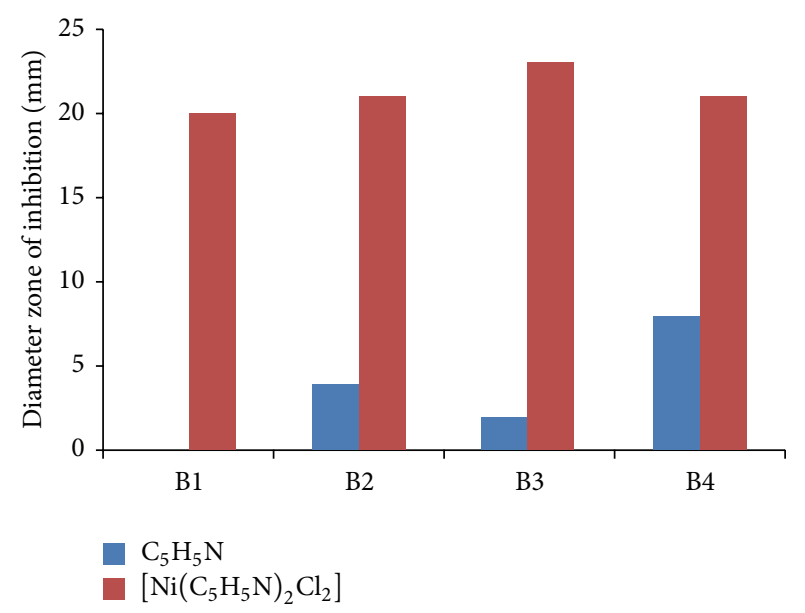

FIgURE 9: Bacterial growth inhibition by the tested ligand and complex.

the antifungal and antibacterial effect were observed. So it appeared interesting to see whether the compounds involved in this study exhibit any such activity or not.

In the present investigation both ligand and complex have been evaluated against human pathogenic bacteria such as Salmonella typhi (B1), Shigella dysenteriae (B2), Escherichia coli (B3), Bacillus cereus (B4), and phytopathogenic fungi such as Macrophomina phaseolina (F1), Alternaria alternata (F2), Fusarium equiseti (F3), Colletotrichums corcolei (F4), and Botryodiplodia theobromae (F5).

The results of the inhibition zones of the selected bacteria due to the effect of ligand and complex are graphically presented in Figure 8. The present work reveals that the complex was more effective against bacteria than its ligand and the data show that $E$. coli was inhibited to the greatest degree by the prepared complex. The results of the percentage inhibition of mycelia growth of the plant pathogenic fungi due to the effect of study are given graphically in Figure 9. The overall results indicated that the present complex has various amounts of effects on the inhibition of mycelial growth. Further (in most of cases) the ligand and complexes are found to show higher inhibition on the growth of Macrophomina phaseolina in comparison with other fungi.

From the above discussion, it can be concluded that nature of ligands and metals plays a significant role in the inhibition of mycelial growth. However, in order to understand the functions responsible for antifungal activities of pyridine and its metal complexes, more studies are needed to be carried out with a series of analogous ligands and their complexes against a series of phytopathogenic fungi and bacteria.

\section{Conclusion}

From analytical and physical some spectral data at four coordinated cis- and trans-structures of the complex were proposed. Measurements of inhibition zones of ligand and complex show that the prepared complex has enhanced antibacterial activity more than ligand. In conclusion, this complex could reasonably be used for the treatment of some common diseases caused by E. coli.

\section{Conflict of Interests}

The authors declare that they have no conflict of interests.

\section{Acknowledgments}

The authors thank the Authority of Bangladesh Council of Scientific and Industrial Research (BCSIR) for providing all support, heartfelt gratitude is due to to Osaka University, Osaka, Japan, for recording $1 \mathrm{H}-\mathrm{NMR}$ and 13C-NMR spectra of the complexes, and also special thanks are due to Chittagong College for assisting them by the support.

\section{References}

[1] N. Raman and S. Ravichandran, "Studies on Schiff base complexes of $\beta$-diketones/ $\beta$-ketoesters with 2,4-dinitrophenylhydrazone and their antimicrobial activities," Polish Journal of Chemistry, vol. 78, no. 11-12, pp. 2005-2012, 2004.

[2] N. Raman and S. Ravichandran, "Effect of substituents on N(1-piperidinobenzyl) acetamide and N-(1-morpholinobenzyl) acetamide and their antimicrobial activity," Asian Journal of Chemistry, vol. 15, no. 3-4, pp. 1848-1850, 2003.

[3] G. Bell, J. Davidson, and H. Scarborough, Textbook of Physiology and Biochemistry, Churchill Livingstone, Edinburgh, UK, 7th edition, 1968.

[4] E. J. Baran, "Metal complexes of carnosine," Biochemistry, vol. 65, no. 7, pp. 789-797, 2000.

[5] R. N. Prasad, K. M. Sharma, and A. Agrawal, "Mixed ligand complexes of $\mathrm{Co}$ (II) containing 5-bromosalicylaldehyde and $\beta$ diketones, hydroxyaryl aldehydes or ketones," Indian Journal of Chemistry, Section A: Inorganic, Physical, Theoretical and Analytical Chemistry, vol. 46, no. 4, pp. 600-604, 2007.

[6] R. Johari, G. Kumar, and S. Singh, "Synthesis and antibacterial activity of M (II) schiff-base complex," Journal of the Indian Chemical Council, vol. 26, pp. 23-27, 2009. 
[7] P. Mittal and V. Uma, "Synthesis, spectroscopic and cytotoxic studies of biologically active new $\mathrm{Co}$ (II), Ni (II), Cu (II) and Mn (II) complexes of Schiff base hydrazones," Der Chemica Sinica, vol. 1, no. 3, pp. 124-137, 2010.

[8] A. Chaubey and S. Pandeya, "Pyridine: a versatile nucleuse in pharmaceutical field," Asian Journal of Pharmaceutical and Clinical Research, vol. 4, pp. 5-8, 2011.

[9] H.-C. Hsu, F.-W. Lin, C.-C. Lai, P.-H. Sua, and C.-S. Yeh, "Photodissociation and theoretical studies of the $\mathrm{Au}^{+}-\left(\mathrm{C}_{5} \mathrm{H}_{5} \mathrm{~N}\right)$ complex," New Journal of Chemistry, vol. 26, no. 4, pp. 481-484, 2002.

[10] W. Guo, H. Liu, and S. Yang, "Photodissociation spectroscopy of $\mathrm{Mg}^{+}$-pyridine complex," International Journal of Mass Spectrometry, vol. 226, no. 2, pp. 291-304, 2003.

[11] D. Y. Wu, M. Hayashi, C. H. Chang, K. K. Liang, and S. H. Lin, "Bonding interaction, low-lying states and excited chargetransfer states of pyridine-metal clusters: pyridine- $\mathrm{Mn}(\mathrm{M}=\mathrm{Cu}$, $\mathrm{Ag}, \mathrm{Au} ; n=2-4)$," The Journal of Chemical Physics, vol. 118, no. 9, pp. 4073-4085, 2003.

[12] C. Guo, Z. Cao, and Q. Zhang, "Theoretical study of dissociative potential energy curves and photodissociation mechanisms of the $\mathrm{Mg}^{+}$-pyridine complex in the low-lying states," Chemical Physics Letters, vol. 386, no. 4-6, pp. 448-453, 2004.

[13] A. Sherman, Encyclopedia of Reagents for Organic Synthesis, edited by L. Paquette, John Wiley \& Sons, New York, NY, USA, 2004.

[14] A. M. K. R. Balan, F. N. Ashok, M. Vasanthi, R. Prabu, and A. Paulraj, "Mixed ligand complexes of nickel(II), copper(II) and zinc(II) with nicotinanilide and thiocyanate," International Journal of Life Science and Pharma Reviews, vol. 3, no. 2, pp. 6775, 2013.

[15] T. Y. Zhang, Waste Minimization in Pharmaceutical Process Development: Principles, Practice and Challenges, Blackwell Science, Oxford, UK, 2002.

[16] S. G. Konda, V. T. Khedkar, and B. Dawane, "Synthesis of some new 2-amino-3-cyano-4-aryl-6-(1-naphthylamino)pyridines as antibacterial agent," Journal of Chemical and Pharmaceutical Research, vol. 2, no. 1, pp. 187-191, 2010.

[17] D. C. Mungra, M. P. Patel, and R. G. Patel, "An efficient onepot synthesis and in vitro antimicrobial activity of new pyridine derivatives bearing the tetrazoloquinoline nucleus," Arkivoc, vol. 2009, no. 14, pp. 64-74, 2009.

[18] D. H. Vyas, S. D. Tala, J. D. Akbari, M. F. Dhaduk, K. A. Joshi, and H. S. Joshi, "Synthesis and antimicrobial activity of some new cyanopyridine and cyanopyrans towards Mycobacterium tuberculosis and other microorganisms," Indian Journal of Chemistry-Section B Organic and Medicinal Chemistry, vol. 48, no. 6, pp. 833-839, 2009.

[19] A. R. Gholap, K. S. Toti, F. Shirazi et al., "Synthesis and evaluation of antifungal properties of a series of the novel 2-amino-5oxo-4-phenyl-5, 6, 7, 8-tetrahydroquinoline-3-carbonitrile and its analogues," Bioorganic and Medicinal Chemistry, vol. 15, no. 21, pp. 6705-6715, 2007.

[20] A. A. Bekhit and A. M. Baraka, "Novel milrinone analogs of pyridine-3-carbonitrile derivatives as promising cardiotonic agents," European Journal of Medicinal Chemistry, vol. 40, no. 12, pp. 1405-1413, 2005.

[21] T. Murata, M. Shimada, S. Sakakibara et al., "Discovery of novel and selective IKK- $\beta$ serine-threonine protein kinase inhibitors. Part 1," Bioorganic and Medicinal Chemistry Letters, vol. 13, no. 5, pp. 913-918, 2003.
[22] A. El-Fotooh, G. Hammam, M. A. Sharaf, A. Nagalaa, and Abd El-Hafeza, Indian Journal of Chemistry, vol. 40, pp. 213-221, 2001.

[23] F. Shi, S. Tu, F. Fang, and T. Li, "One-pot synthesis of 2-amino-3cyanopyridine derivatives under microwave irradiation without solvent," Arkivoc, vol. 2005, no. 1, pp. 137-142, 2005.

[24] D. G. Kerfoot, "Nickel," in Ullmann's Encyclopedia of Industrial Chemistry, 2002.

[25] B. Wood and C. Reilly, "Interaction of nickel and plant," in Mineral Nutrition and Plant Diseases, pp. 217-247, 2007.

[26] S. Khan and A. Moheman, "Effect of heavy metals (cadmium \& nickel) on the seed germination, growth and metals uptake by Chilli (Capsicum frutescens) and sunflower plants (Helianthus annuus)," Pollution Research, vol. 25, no. 1, pp. 99-104, 2006.

[27] M. Poonkothai and B. S. Vijayavathi, "Nickel as an essential element and a toxicant," International Journal of Environmental Sciences, vol. 1, pp. 285-288, 2012.

[28] P. G. Avaji and S. A. Patil, "Synthesis, spectral characterization and microbiological studies of $\mathrm{Co}(\mathrm{II}), \mathrm{Ni}(\mathrm{II})$ and $\mathrm{Cu}(\mathrm{II})$ complexes with some novel 20-membered macrocyclic hydrazino1,2,4-triazole Schiff bases," Journal of Enzyme Inhibition and Medicinal Chemistry, vol. 24, no. 1, pp. 140-150, 2009.

[29] S. Sanap and R. Patil, "Synthesis, characterisation and biological activity of chiral mixed ligand Ni (II) complexes," Research Journal of Pharmacutical Sciences, vol. 2, no. 1, pp. 1-10, 2013.

[30] M. S. Refat, I. M. El-Deen, M. A. Zein, A. M. A. Adam, and M. I. Kobeasy, "Spectroscopic, structural and electrical conductivity studies of $\mathrm{Co}(\mathrm{II}), \mathrm{Ni}(\mathrm{II})$ and $\mathrm{Cu}(\mathrm{II})$ complexes derived from 4acetylpyridine with thiosemicarbazide," International Journal of Electrochemical Science, vol. 8, no. 7, pp. 9894-9917, 2013.

[31] S. Anitha, J. Karthikcyan, and A. N. Shctty, "Synthesis and characterization of nickel (II) complex of p-[N, N-bis-(2chloroethyl) amino] benzaldehyde-4-ethyl thiosemicarbazone," Indian Journal of Chemistry, Section A: Inorganic, Physical, Theoretical and Analytical Chemistry, vol. 52, no. 1, pp. 45-50, 2013.

[32] D. Antonsen and D. T. Meshri, Nickel Compounds, Kirk-Othmer Encyclopedia of Chemical Technology, 2005.

[33] A. I. Busev, V. G. Tipcova, and V. M. Ivanov, Analytical Chemistry of Rare Elements, Mir Publishers, Moscow, Russia, 1981.

[34] T. G. Roy, S. K. S. Hazari, B. K. Dey, H. A. Miah, F. Olbrich, and D. Rehder, "Synthesis and antimicrobial activities of isomers of $N(4), N(11)$-dimethyl-3, 5,7,7,10,12,14,14-octamethyl-1,4,8,11tetraazacyclotetradecane and their nickel(II) complexes," Inorganic Chemistry, vol. 46, no. 13, pp. 5372-5380, 2007.

[35] T. G. Roy, S. K. S. Hazari, B. K. Dey et al., "Synthesis, electrolytic behaviour and antimicrobial activities of cadmium complexes of isomers of 3, 10-C-meso-3, 5, 7, 7, 10, 12, 14, 14-octamethyl$1,4,8$, 11-tetraazacyclotetradecane," Journal of Coordination Chemistry, vol. 60, no. 14, pp. 1567-1578, 2007.

[36] M. A. Affan, S. W. Foo, I. Jusoh, S. Hanapi, and E. R. T. Tiekink, "Synthesis, characterization and biological studies of organotin(IV) complexes with hydrazone ligand," Inorganica Chimica Acta, vol. 362, no. 14, pp. 5031-5037, 2009.

[37] P. F. Rapheal, E. Manoj, M. R. P. Kurup, and E. Suresh, "Structural and spectral studies of novel Co(III) complexes of $\mathrm{N}(4)$-substituted thiosemicarbazones derived from pyridine-2carbaldehyde," Polyhedron, vol. 26, no. 3, pp. 607-616, 2007.

[38] P. Kamalakannan and D. Venkappayya, "Synthesis and characterization of cobalt and nickel chelates of 5-dimethylaminomethyl-2-thiouracil and their evaluation as antimicrobial and 
anticancer agents," Journal of Inorganic Biochemistry, vol. 90, no. 1-2, pp. 22-37, 2002.

[39] M. S. Hossain, S. Easmin, M. S. Islam, and M. Rashid, "Novel thiocyanato complexes with potent cytotoxic and antimicrobial properties," Journal of Pharmacy and Pharmacology, vol. 56, no. 12, pp. 1519-1525, 2004.

[40] G. Č́́k, H. Bujdáková, and F. Šeršeň, "Study of fungicidal and antibacterial effect of the $\mathrm{Cu}(\mathrm{II})$-complexes of thiophene oligomers synthesized in ZSM-5 zeolite channels," Chemosphere, vol. 44, no. 3, pp. 313-319, 2001.

[41] M. R. Islam, S. M. Islam, A. S. Noman et al., "Biological screening of a novel nickel (II) tyrosine complex," Mycobiology, vol. 35, no. 1, pp. 25-29, 2007. 

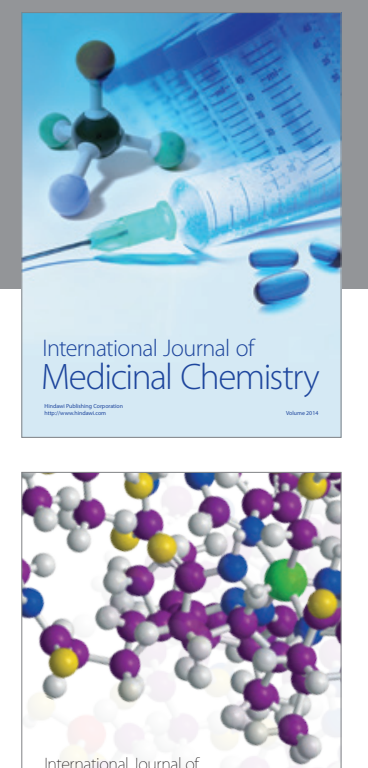

\section{Carbohydrate} Chemistry

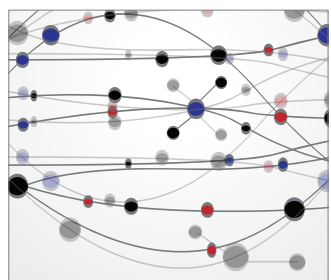

The Scientific World Journal
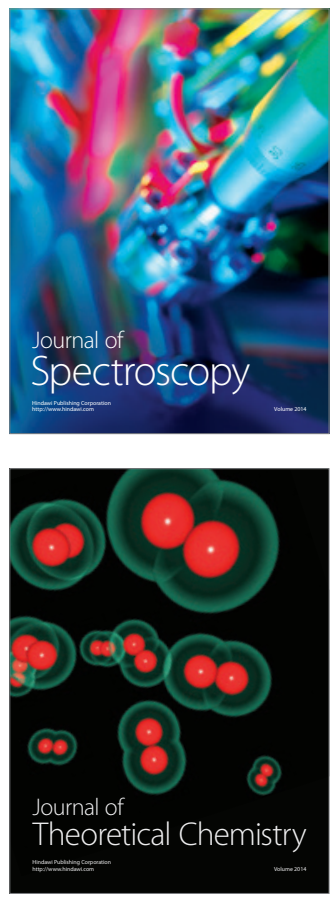
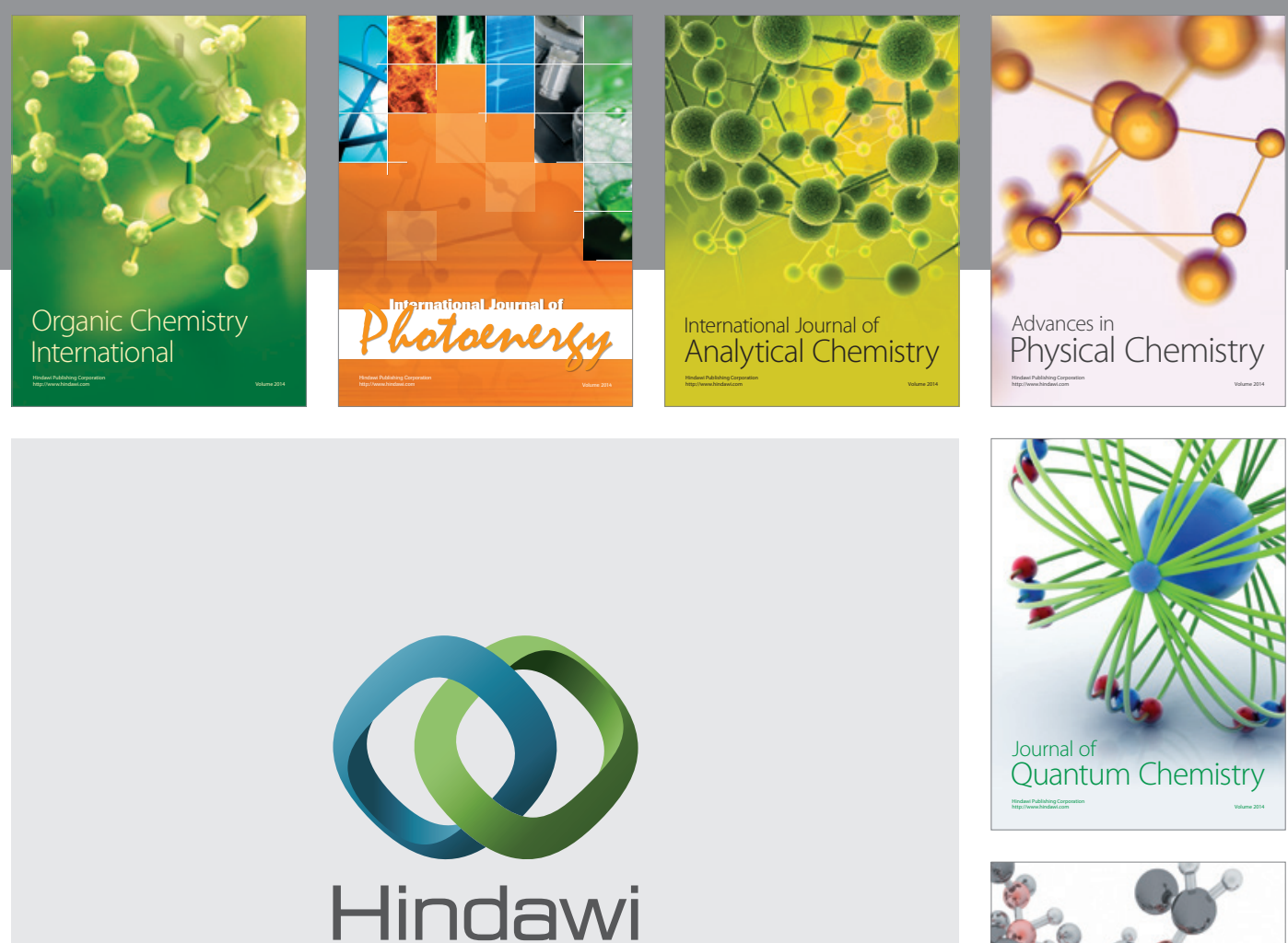

Submit your manuscripts at

http://www.hindawi.com

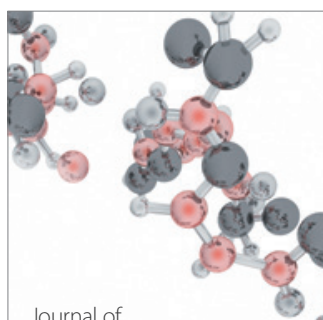

Analytical Methods

in Chemistry

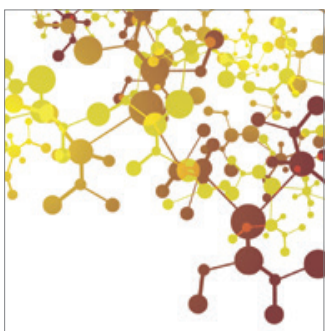

Journal of

Applied Chemistry

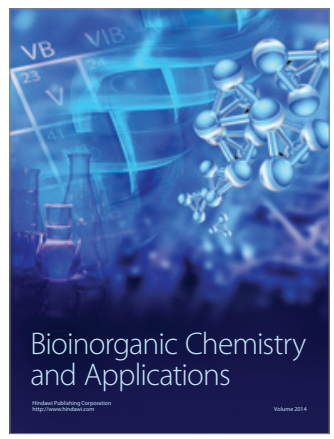

Inorganic Chemistry
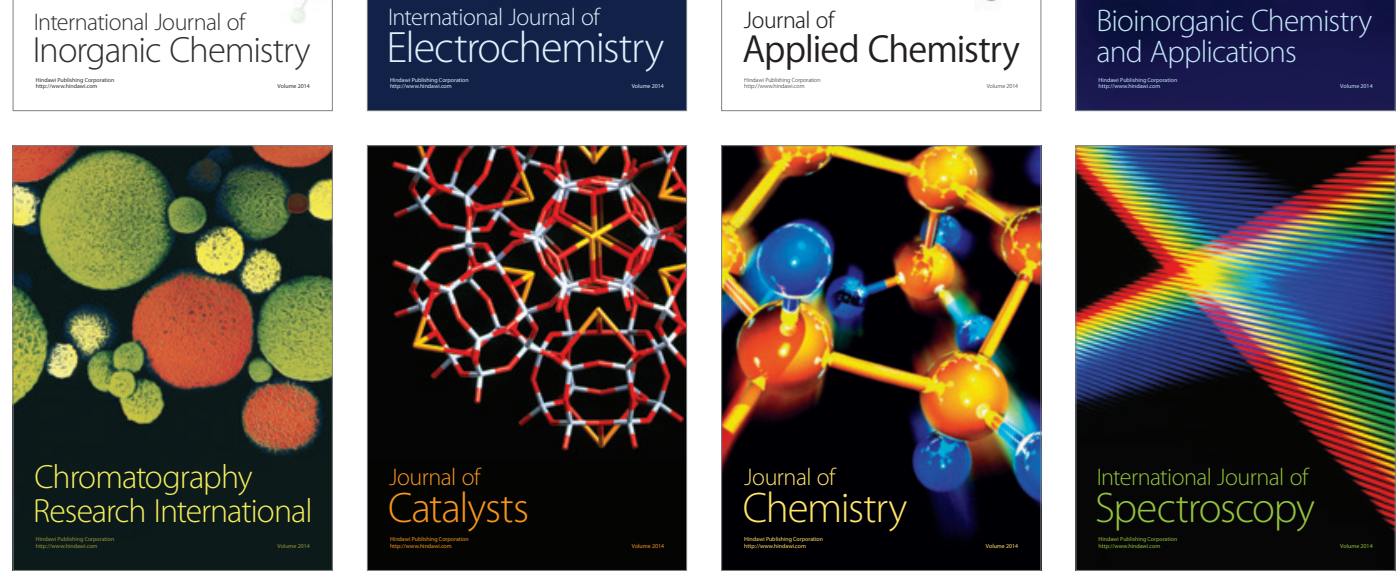